Tarbill, G. L., A. M. White, and P. N. Manley. 2018. The persistence of Black-backed Woodpeckers following delayed salvage logging in the Sierra Nevada. Avian Conservation and Ecology 13(1):16. https://doi.org/10.5751/ACE-01206-130116

Copyright (C) 2018 by the author(s). Published here under license by the Resilience Alliance.

Research Paper

\title{
The persistence of Black-backed Woodpeckers following delayed salvage logging in the Sierra Nevada
}

\author{
Gina L. Tarbill ${ }^{1,2,3}$, Angela M. White ${ }^{1}$ and Patricia N. Manley ${ }^{1}$ \\ ${ }^{1}$ USDA Forest Service, Pacific Southwest Research Station, ${ }^{2}$ Oak Ridge Institute for Science and Education, ${ }^{3}$ University of \\ California, Davis
}

\begin{abstract}
The Black-backed Woodpecker (Picoides arcticus) is a snag-associated species that colonizes and utilizes patches of burned forests typically within 10 years of fire. Previous research has indicated that salvage logging, the removal of dead and dying trees from burned forests, has a negative effect on nesting densities of Black-backed Woodpeckers. One strategy proposed to ameliorate the impacts of dead tree removal on Black-backed Woodpeckers is to retain patches, or islands, of dense snags within the salvage matrix, but this approach remains largely untested. Following the Angora fire of South Lake Tahoe, CA several snag islands were retained within the larger salvage prescription to conserve habitat for Black-backed Woodpeckers and other snag-associated species. In this observational study, we evaluate whether these snag islands were effective at maintaining Black-backed Woodpecker populations following logging operations that covered $45 \%$ of the burned area. We systematically searched the postfire landscape for Black-backed Woodpecker nests for two years before and after salvage operations and compared nesting densities between logged and unlogged areas. Similar to other studies, we found that nest densities at the stand scale declined significantly in areas that were salvage logged, but Black-backed Woodpeckers did nest in both snag islands and in other peripheral unlogged areas, indicating that this approach may help balance habitat for wildlife with management needs at the scale of the fire. In this study, the removal of dead trees, which is usually implemented in the first two years following fire, did not occur until the fourth year, which may have also contributed to the persistence of Black-backed Woodpeckers postlogging.
\end{abstract}

\section{Persistance du Pic à dos noir après une coupe de récupération différée dans la Sierra Nevada}

RÉSUMÉ. Le Pic à dos noir (Picoides arcticus), une espèce associée aux chicots, colonise et utilise des îlots de forêts brûlées, généralement dans la décennie suivant un feu. Des recherches antérieures ont montré que la coupe de récupération, qui enlève les arbres morts et mourants des forêts brûlées, avait des effets négatifs sur la densité de Pics à dos noir nicheurs. Une des stratégies proposées pour réduire les impacts de l'enlèvement des arbres morts sur les pics est de conserver des îlots denses de chicots dans la matrice de récupération, mais cette approche n'a pas encore vraiment été testée. À la suite du feu Angora à South Lake Tahoe, en Californie, plusieurs îlots de chicots ont été conservés dans le cadre de la prescription de récupération, afin de conserver de l'habitat pour les Pics à dis noir et les autres espèces associées avec les chicots. Dans la présente étude observationnelle, nous avons évalué si ces îlots de chicots remplissaient leur fonction de maintenir les populations de Pics à dos noir à la suite des opérations de récolte de bois qui ont couvert $45 \%$ de l'aire brûlée. À même le paysage brûlé, nous avons systématiquement cherché des nids de ce pic, 2 ans avant et après les opérations de récupération, et avons comparé la densité de nidification entre les zones récoltées ou non. Similairement à d'autres études, nous avons découvert que la densité de nids à l'échelle du peuplement diminuait significativement dans les secteurs ayant subi une coupe de récupération, mais les Pics à dos noir ont niché dans les îlots de chicots et dans les autres secteurs périphériques non récoltés, ce qui laisse entendre que cette approche pourrait contribuer à équilibrer l'habitat pour la faune ayant des besoins en matière d'aménagement à l'échelle du feu. Dans la présente étude, l'enlèvement des arbres morts, qui s'effectue habituellement dans les deux premières années suivant un feu, ne s'est produit qu'à la quatrième année, ce qui a peut-être aussi contribué à la persistance des Pics à dos noir après coupe.

Key Words: Black-backed Woodpecker; postfire; salvage logging; snag island; snag retention

\section{INTRODUCTION}

The Black-backed Woodpecker (Picoides arcticus) rapidly colonizes recently burned coniferous forests where it nests and forages in dense stands of fire-killed trees (Nappi and Drapeau 2009, Saab et al. 2009, Nappi et al. 2015). This population dynamic is attributed to the dependence of Black-backed Woodpeckers on their primary prey, the larvae of wood-boring beetles (Villard and Benninger 1993, Murphy and Lehnhausen 1998, Tremblay et al. 2016). Wood-boring beetles (Coleoptera:
Buprestidae and Cerambycidae) lay their eggs in trees that are damaged or killed, but retain adequate moisture to provide food for larvae (Furniss and Carolin 1977). Freshly hatched larvae burrow deep into the wood where they take one to several years to mature (Furniss and Carolin 1977). Thus, recently burned landscapes offer suitable substrates for the recruitment of woodboring beetles, and their avian predator, the Black-backed Woodpecker, for a limited time following the fire (DeNitto et al. 2000), which is partially determined by synchronicity in tree 
mortality. In stand-replacing fires typical of the boreal forests, tree mortality tends to occur in a pulse, with an abundance of resources available to wood-boring beetles in the first years after fire only. In these regions, populations of Black-backed Woodpecker tend to peak in the first year after fire and then drop to near zero within the next two years (Nappi and Drapeau 2009). In contrast, midelevation forests of the Sierra Nevada, frequent fires historically burned at low to moderate severity with some high severity effects (Beaty and Taylor 2008, Collins and Stephens 2010) created by local fuel conditions (Coppoletta et al. 2015), climate (Taylor and Beaty 2005, Westerling et al. 2006), and topography (Beaty and Taylor 2002). This heterogeneity results in tree mortality patterns that vary spatially and temporally, with snags continuously gained and lost through mortality and attrition (Russell et al. 2006). Black-backed Woodpeckers of western coniferous forests occupy burned areas up to 10 years postfire, generally achieving their highest density in years four to five (Saab et al. 2007), followed by a slow decline over the subsequent five years (Saab et al. 2007, Saracco et al. 2011).

However, following Euro-American settlement efficient firesuppression practices reduced the area of forest that burned annually in mixed conifer forest (North et al. 2012), reducing habitat availability for Black-backed Woodpeckers. This was likely exacerbated by salvage logging, the removal of dead and dying trees from a disturbed landscape. Because of the economic and social value of timber, salvage logging has been in practice in the U.S. since at least the early 1900s, when it was recommended that burned areas be clear cut immediately following fire (Buttrick 1912). Historically, snags were considered wasteful, and therefore removed from both burned and green forests until the late 1960s, when the value of snags for wildlife was demonstrated (McClelland and Frissell 1975, Bull and Meslow 1977, Raphael and White 1978). This led to the establishment of "snagretention" policies that called for leaving some snags on postfire landscapes to provide habitat for wildlife. The level of snag retention varied widely, from leaving only "unmerchantable" snags $(<8 \mathrm{~cm}$ at diameter at breast height [dbh]; Purdon et al. 2002), to leaving anywhere from five snags per ha (Eklund et al. 2009) to 100 snags per ha near stream environment zones to protect water quality (U.S. Forest Service 2010a). Most current salvage prescriptions in the western United States retain 8 to 15 of the largest snags per hectare and are largely based on optimal snag densities estimated for wildlife in green forests (Thomas 1979, Bull et al. 1997). These snag densities may be too low to fully support the suite of wildlife species that exploit postfire habitat, including the Black-backed Woodpecker (Nappi et al. 2004, Nappi and Drapeau 2011, White et al. 2015). Currently, salvage logging is typically implemented in the first three years after fire to reduce threats to public safety and optimize the quality of the wood for timber and associated market value (Richmond and Lejune 1945, Sessions et al. 2004). Thus, most logging occurs during early woodpecker colonization (Murphy and Lehnhausen 1998, Sarraco et al. 2011).

Complicating the issue, the removal of dead and dying trees is considered by some to be necessary to meet reforestation objectives. Fire suppression, logging, mining, grazing, and climate have interacted to affect the fire regime in the Sierra Nevada. Contemporary forests tend to burn with higher flame length and rates of spread, resulting in large contiguous patches of standing dead trees (Taylor et al. 2013). This increase in the size of high severity patches has raised concerns that some salvage logging and subsequent replanting may be necessary to re-establish prefire forested conditions where seed banks are destroyed and no trees survive to serve as sources (Goforth and Minnich 2008, Collins and Roller 2013). Additionally, extensive stand-replacing fire could promote subsequent stand-replacing fire (Thompson and Spies 2010, Lydersen et al. 2017) that could lead to long-term state changes from forest to shrubland (Collins and Skinner 2014). Because fuel loads may be one of the most influential and controllable variables driving future high-severity fire (Coppoletta et al. 2015, Lydersen et al. 2017), stopping the high severity cycle may require removal of some snags. Active management of burned forests that includes salvage logging and the removal of nonmerchantable trees (postfire harvest), replanting, and shrub removal may be necessary in some areas to increase the probability that coniferous forest persists at desirable levels in postfire landscapes (Sessions et al. 2004). Thus, the retention of dead trees to support native wildlife, such as the Black-backed Woodpecker and other snag-dependent species, can present a challenge to reforestation objectives.

In many managed, burned forests, patches of snags are retained in the postfire landscape for environmental, i.e., water quality, and logistical, i.e., steep slopes and limited access, reasons. In contrast, "snag islands," i.e., patches of standing dead trees retained within the larger salvage matrix, are now included in many prescriptions of postfire landscapes, specifically to provide habitat for early-seral species. These areas provide an unutilized opportunity to investigate if these patches meet the habitat needs of Black-backed Woodpeckers and other snag-associated species, providing an effective balance between long-term forest management objectives and short- and long-term wildlife habitat needs. As high-severity fires become larger and more frequent in the west (Miller et al. 2009), the need to understand if and how the retention of snag patches can be used to meet Black-backed Woodpecker needs is increasingly important. Black-backed Woodpeckers are found in boreal and montane coniferous forests, with highest densities reported in recently burned patches. These woodpeckers are considered specialist predators of wood-boring larva on account of morphological and behavioral adaptations that enable them to extract burrowing prey more efficiently than their competitors (Tremblay et al. 2016). In recently burned forest (1-3 year-old), Black-backed woodpeckers foraged in high severity areas immediately after fire, although they preferred moderately burned snags as foraging substrate (Nappi et al. 2010). In older (6-8 year-old) burns, larger snags in dense stands were selected for foraging; burn severity was not influential (Dudley et al. 2012) and foraging occurred at the fire periphery and in green patches (Dudley and Saab 2007). Home range size estimates vary from 24 to 400 ha, with larger home ranges in older fires (Dudley and Saab 2007) and those with lower snag basal area (Tingley et al. 2014). However, concentrated foraging patches within home ranges were approximately 4 ha in size (Dudley and Saab 2007). Nest cavities are generally built in small diameter $(\sim 30 \mathrm{~cm})$ sound snags in dense stands (Tremblay et al. 2016). This suggests that snag retention focused on conserving Black-backed Woodpecker habitat should include patches at least 4 ha in size, with dense stands of high to moderately burned, mixed diameter snags. 
Fig. 1. Location of Black-backed Woodpecker (Picoides arcticus) nests before and after logging in the 2007 Angora fire in the Lake Tahoe basin, California.

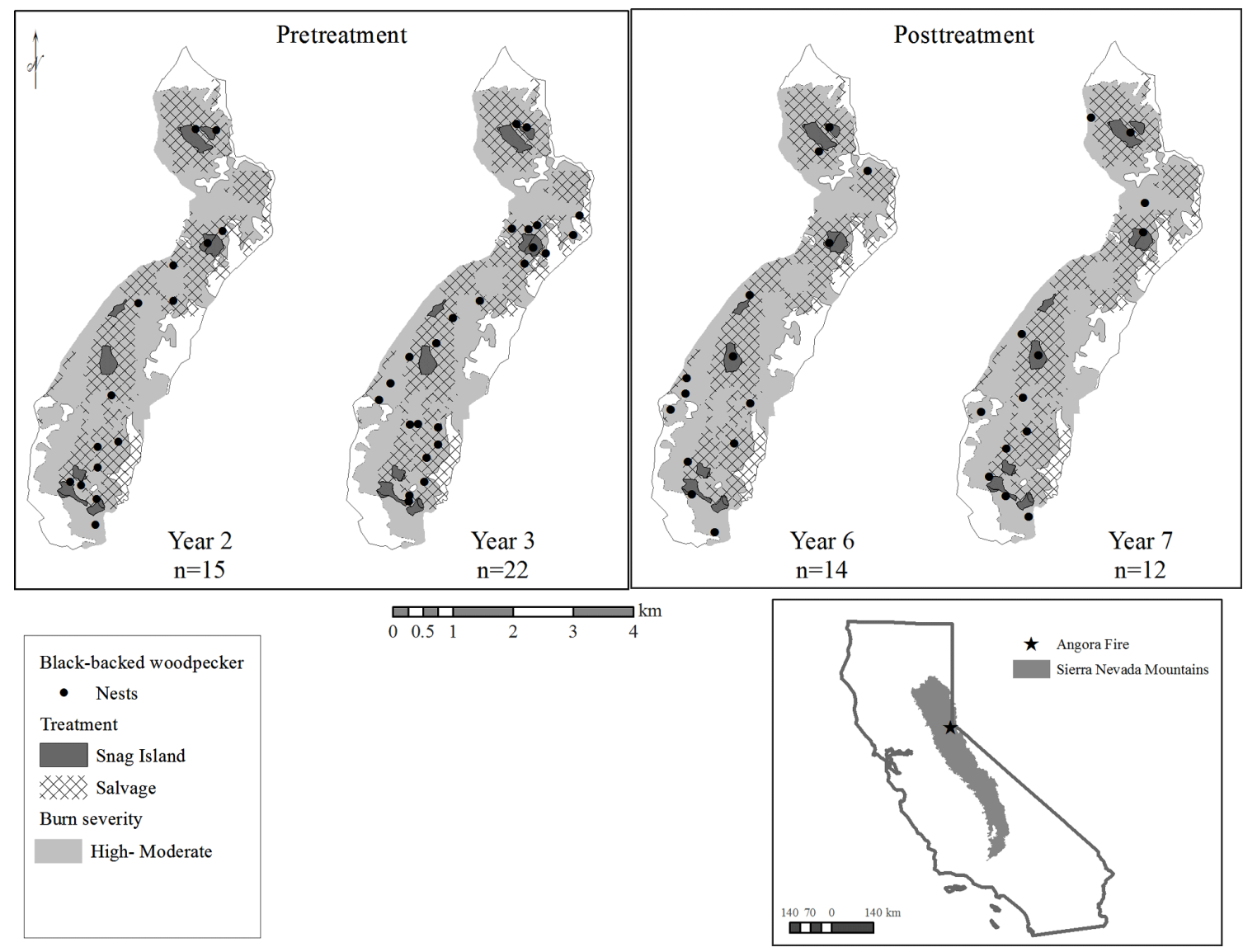

We present an observational study of Black-backed Woodpeckers in the Angora fire that burned in South Lake Tahoe, California in 2007 in which $\sim 45 \%$ of the burned forest was treated by removing fire-killed and damaged trees. Postfire management of this burned area was unique in several respects. First, within the interior of the burn several snag islands were left unlogged with the objective of maintaining areas with higher snag densities suitable for complex, early-seral species. Second, some high to moderately burned areas along the periphery of the fire were also not logged because of logistical constraints. Third, because of public concerns related to the loss of wildlife habitat, salvage logging operations were not implemented until 2011, four years after the fire. The initial plan to log this fire was complicated by litigation, and the prescription was altered several times, making a robust balanced, experimental design difficult. However, we took advantage of this unusual prescription to observe how snag islands and other unsalvageable areas are used for nesting by Black-backed Woodpeckers. We asked how management of the Angora fire influenced Black-backed Woodpeckers at three different scales: the fire scale, the stand scale, and the nest scale by comparing use of these areas two years prior to and two years following salvage logging.

\section{METHODS}

\section{Study area}

We searched for Black-backed Woodpecker nests in the Angora fire that burned approximately 1254 ha of montane coniferous forest ( $1900 \mathrm{~m}$ to $2300 \mathrm{~m}$ above sea level) in June and July 2007. The Angora fire occurred on the southwest shore of Lake Tahoe $\left(38.91^{\circ} \mathrm{N}, 120.04^{\circ} \mathrm{W}\right)$, approximately $140 \mathrm{~km}$ east of Sacramento, California in an area with a high degree of intermixed private and public land adjacent to large expanses of undeveloped public land. Fire severity was classified based on satellite-derived measures of relative-differenced normalized burn ratio (RdNBR) calibrated to canopy cover mortality (hereafter, burn severity; Miller et al. 2009). Although burn severity was primarily moderate ( $25-75 \%$ tree mortality) and high severity ( $\geq 75 \%$ tree mortality), it did vary around the perimeter of the fire footprint, resulting in a range of postfire habitat conditions (Fig. 1). Prefire forests were dominated by mature Jeffrey pine (Pinus jeffreyii) and white fir (Abies concolor) with red fir (A. magnifica) found at the highest elevations and incense cedar (Calocedrus decurrens), sugar pine ( $P$. lambertiana), and lodgepole pine ( $P$. contorta) found at the lower elevations (Safford et al. 2009). Historic fire return intervals for mixed conifer forest of the Sierra Nevada are estimated at 525 years (McKelvey et al. 1996), but fire has been excluded from 
this region since the late 1800s (Beaty and Taylor 2008). The Lake Tahoe basin was heavily clear cut in the later part of the 19th century to meet the demand for wood in the silver mines (Lindström et al. 2000). Because of recent concerns over fire in the wildland- urban interface, some areas were thinned in the decade prior to the fire to reduce fuels (Safford et al. 2009), however, much of the area comprised dense stands of small diameter trees with many ladder fuels (Taylor et al. 2013).

\section{Nest searching}

We utilized a U.S. Forest Service (USFS) grid of points spaced 400-m apart across the fire area to systematically search for Blackbacked Woodpecker nests within the fire footprint. Although Black-backed Woodpeckers typically build nests in forests that burn at high severity (Saab and Dudley 1998, Hutto 2006), they are also known to use green areas (Tremblay et al. 2009, 2015, Fogg et al. 2014), so we searched the full spectrum of burn conditions. We selected a stratified random sample of survey points from this grid and augmented the sample with 11 additional survey points on lands managed by the California Tahoe Conservancy (CTC) to increase representation of available landscape conditions. In total, 91 unique survey points were sampled over the four years sampled, although survey effort varied across years because of logistical constraints.

Nest searches were conducted during the breeding season (MayJune) two and three years following the fire and prior to logging operations, and again six and seven years after fire, following salvage operations, which occurred four years after fire. At each survey point, observers systematically searched for Black-backed woodpeckers and active nest cavities (Martin and Geupel 1993) within a $100-\mathrm{m}$ radius ( $2 \mathrm{ha}$ ) of the survey point for a minimum of one hour. Between three and six survey points were searched each day and each point was surveyed three times over the breeding season, with at least one week between surveys. Although the minimum amount of time spent searching for birds and cavities was standardized across all treatments and years, once a bird or cavity was located, no maximum time was set to determine if the cavity was active and observers were encouraged to follow birds outside of the $100-\mathrm{m}$ radius to find active nests.

\section{Salvage logging prescriptions and implementation}

Based on the management action and purpose, we divided the postfire landscape into three "treatments": contiguous areas where all or most dead trees were removed (salvage, $n=14$ ), contiguous areas retained specifically for Black-backed Woodpeckers and other early-seral associates (snag islands, $\mathrm{n}=$ 8 ), and contiguous areas left unharvested to address other management needs (no-salvage, $n=6$ ). Area-weighted mean burn severities were highest in the snag islands $(98 \pm 5 \%)$, and moderate in both no-salvage $(69 \pm 32 \%)$ and salvage $(73 \pm 25 \%)$ treatments (Appendix 1). Salvage treatments occurred on $\sim 525$ ha of forested areas in which a conventional salvage prescription was implemented calling for the removal of all snags and dying trees with the exception of 10 of the largest snags per ha. In contrast, eight snag islands (total of $\sim 54 \mathrm{ha}$ ) established in the interior of the fire were not logged specifically to provide high-density pockets of snags for wildlife within salvage treatments (Fig. 1,
Appendix 1). Delineation of snag islands was performed by an interdisciplinary team of managers to provide high-quality habitat for multiple snag-associated species (U.S. Forest Service $2010 a$ ). The resulting snag islands were often, but not exclusively, located in areas with high seasonal soil moisture, limited road and equipment access, or steep, rocky slopes. No-salvage sites ( $\sim 600$ ha) were primarily located on the periphery of the fire and included areas that were too steep to salvage ( $>30 \%$ slope), dominated by unmerchantable wood $(<8 \mathrm{~cm} \mathrm{dbh})$, or inaccessible to logging equipment. A secondary treatment was implemented in stream environment zones that retained a higher density of snags (100 snags per ha); however, because this treatment was so limited in scope $(\sim 18$ ha, $n=1)$, we did not include it in our analysis. Treatment boundaries used in our analyses were provided in the U.S. Forest Service (2010b).

\section{Effects of treatment at the fire scale}

Approximately $43 \%$ of the Angora fire was salvage logged, primarily in high severity burns in the interior of the fire. Four percent of the burned area was set aside as snag islands to support early-seral wildlife. The remaining $\sim 52 \%$ of the burned area was classified as no-salvage because of various constraints and management objectives. Because of the time periods sampled, the status of the population in year 4 and 5 after fire was unknown, but Saab et al. (2007) found that densities of Black-backed Woodpeckers in mixed conifer forests in the intermountain west peaked during this time frame. Therefore, any decline in Blackbacked Woodpecker populations in years 6 and 7 after fire may be due to declining prey populations regardless of any salvage effects. To best address this query, our pre- and postlogging sampling design focuses on relative differences, thereby minimizing bias associated with time since fire.

\section{Stand-scale comparisons}

We quantified the number of nests found each year in each treatment unit. To account for differences in survey effort across years, we used the USFS grid of points to delineate the fire area into $200 \mathrm{~m} \mathrm{X} 200 \mathrm{~m}$ pixels (4 ha), with the sampling point at the center point of each grid. We then classified each grid cell as searched within a given year if an active survey point or a nest was found within that cell in that year. Pixels with nests were included because birds were often followed outside the $100-\mathrm{m}$ radius plot, extending the area searched. Because Black-backed Woodpecker nests were only found in areas that burned at moderate to high severity, we removed any unburned or low severity areas before calculating search area by treatment (Table 1).

We used a generalized linear model (GLM) with the count of nests in each unit as a Poisson-distributed variable to compare nest densities by treatment type (R 3.2.4, R Development Core Team 2018). The number of years since fire, treatment prescription, and their interaction were used as fixed effects, with the search area included as an exposure variable. The effect of years since fire was not significant, so we reran the model pooling nests into pre- or postlogging periods. We used the lsmeans package in $\mathrm{R}$ (Lenth 2016) to obtain pairwise differences in nest densities with Tukey's method for correcting for multiple comparisons. 
Table 1. Search area (SA) and number of nests by time since fire and treatment.

\begin{tabular}{|c|c|c|c|c|c|c|c|}
\hline Treatment & $\begin{array}{c}\text { Total SA } \\
\text { (ha) }\end{array}$ & Total nests & $\begin{array}{l}\text { Nest density per } \\
100 \text { ha }\end{array}$ & $\begin{array}{c}\text { Total SA } \\
\text { (ha) }\end{array}$ & Total nests & $\begin{array}{c}\text { Nest density per } \\
100 \text { ha }\end{array}$ & $\begin{array}{l}\text { Mean nest density } \\
\text { per } 100 \text { ha }\end{array}$ \\
\hline & & Year 2 & & & Year 3 & & Prelogging \\
\hline No-salvage $(n=14)$ & 328.36 & 2 & 0.61 & 405.48 & 3 & 0.74 & 0.67 \\
\hline Snag island $(\mathrm{n}=8)$ & 50.47 & 1 & 1.98 & 54 & 2 & 3.70 & 2.84 \\
\hline Salvage $(n=6)$ & 412.74 & 12 & 2.91 & 459.98 & 17 & 3.70 & 3.30 \\
\hline \multirow[t]{2}{*}{ Total } & 791.57 & 15 & 1.89 & 919.46 & 22 & 2.39 & 2.14 \\
\hline & & Year 6 & & & Year 7 & & Postlogging \\
\hline No-salvage $(n=14)$ & 405.21 & 8 & 1.97 & 403.45 & 7 & 1.74 & 1.85 \\
\hline Snag island $(\mathrm{n}=8)$ & 54 & 3 & 5.56 & 54 & 4 & 7.41 & 6.48 \\
\hline Salvage $(n=6)$ & 460.01 & 3 & 0.65 & 459.98 & 1 & 0.22 & 0.43 \\
\hline Total & 919.22 & 14 & 1.52 & 917.43 & 12 & 1.31 & 1.42 \\
\hline
\end{tabular}

\section{Nest-scale comparisons}

Although Black-backed Woodpeckers may nest in salvage logged areas, this may represent suboptimal habitat. To best address this within the constraints of this study, we compared nest-site characteristics by treatment type prior to and following logging operations. Because the first few years after fire are the most productive for Black-backed Woodpeckers (Saab et al. 2007, Nappi and Drapeau 2009), the habitat selected in this time period likely represents the best available habitat. If characteristics were not significantly different over treatment type and time, this suggests that high quality, or at least comparable, nesting habitat was still available on the landscape.

To investigate how characteristics at the nest site changed following logging relative to treatment type, we collected cavity height, dbh, and decay class data for each nest tree. Decay class was estimated with a 5-class method that uses visual cues, such as retention of fine branches and amount of bark sloughing (Cline et al. 1980). More quantitative assessments of snag decay are better predictors of suitability of nesting substrates (Lorenz et al. 2015); however, we believe the method we used, when applied consistently, provides a fair measure of relative decay between sampling periods and treatment type. Snag density in proximity to nest trees has been shown to be an important predictor for Black-backed Woodpeckers nest site selection (Nappi and Drapeau 2011, Seavy et al. 2012, Tarbill et al. 2015) and is altered by salvage logging; therefore, we tallied all dead trees by diameter class (small: $15-28 \mathrm{~cm}$, medium: $28-61 \mathrm{~cm}$, large: $>61 \mathrm{~cm} \mathrm{dbh}$ ) in an 0.04 ha area around the nest tree. Previous research in the Angora fire indicated that the 0.04 ha area around nest sites is effective at quantifying differences in habitat selection by Blackbacked Woodpeckers (Tarbill 2010). In addition, we calculated the area-weighted burn severity within a $100-\mathrm{m}$ buffer of each nest tree. Although this area is smaller than home range estimates (Tingley et al. 2014), it does provide an estimate of the severity at the nest scale.

We used analysis of variance (R 3.2.4, R Development Core Team 2018) to compare differences at the nest site in burn severity, cavity height, dbh, decay class, and snag density. Sampling period (years pooled into pre- and postlogging) and treatment prescription (salvage, no-salvage, or snag island) and their interaction were fixed effects in the analysis. We used sampling period because we were not interested in annual changes in nest-site characteristics, but instead in differences due to habitat changes created by logging and succession. For example, both salvage and natural attrition over time will remove the smallest snags, resulting in higher average dbh of remaining snags. We used $\alpha=0.05$ to determine statistical significance.

\section{RESULTS}

\section{Effects of treatments at the fire scale}

We found a total of 66 Black-backed Woodpecker nests in the four years of our study: 39 nests prelogging (15 nests in year 2 , 24 nests in year 3 ), and 27 nests postlogging (14 nests in year 6 , and 13 nests in year 7; Fig. 1). Three of these nests (2 prelogging and 1 postlogging) were located in the stream environment zone and were excluded from further analysis because of the lack of replication of this treatment type. Search areas were similar across years, with 792 ha searched in year 2, 919 ha searched in year 3 and year 6, and 917 ha searched in year 7 (Table 1). Densities of Black-backed Woodpecker nests per 100 ha of moderate to highly burned forest were 1.89 in year 2, 2.39 in year 3, 1.41 in year 6 , and 1.42 in year 7.

\section{Stand-scale comparisons}

Average nest densities of the Black-backed Woodpecker varied based on sampling period and treatment type (Fig. 2). Results of our analysis indicated that prior to any logging, salvage units had higher average nest density than no-salvage units (estimate $=4.88$, $\mathrm{SE}=2.86, z=3.27, p=0.01$ ), but average nest densities in salvage units did not differ significantly from snag islands (estimate = $1.16, \mathrm{SE}=0.70, z=-0.24, p=0.99$ ). Following logging, average nest density decreased significantly in salvage units (estimate $=$ 7.64, $\mathrm{SE}=4.08, z=3.81, p<0.01$ ), whereas there was no significant change in average nest densities for no-salvage units (estimate $=0.37, \mathrm{SE}=0.19, z=-1.94, p=0.38$ ) nor snag islands (estimate $=0.44, \mathrm{SE}=0.31, z=-1.18, p=0.85$ ) between pre- and postlogging sampling periods. However, average nest densities were significantly higher in snag islands than in salvage units in the postlogging sampling period (estimate $=0.07, \mathrm{SE}=0.04, \mathrm{z}$ $=-4.31, p<0.01)$ despite supporting similar nest densities prelogging (Table 1). Snag islands used for nesting varied in size, with an average patch area of $7.9 \pm 3.9$ ha in year 6 and $11.4 \pm 4.1$ ha in year 7. The smallest patch used for nesting was 3.4 ha, but it was located very close $(\sim 100 \mathrm{~m})$ to a larger, unoccupied patch 
Fig. 2. Nest densities before and after logging by treatment type. Mean nest densities before and after treatment were compared with ANOVA; bars marked with the different letters are significantly different $(\alpha=0.05)$. Lines represent $95 \%$ confidence intervals from the Poisson distribution.
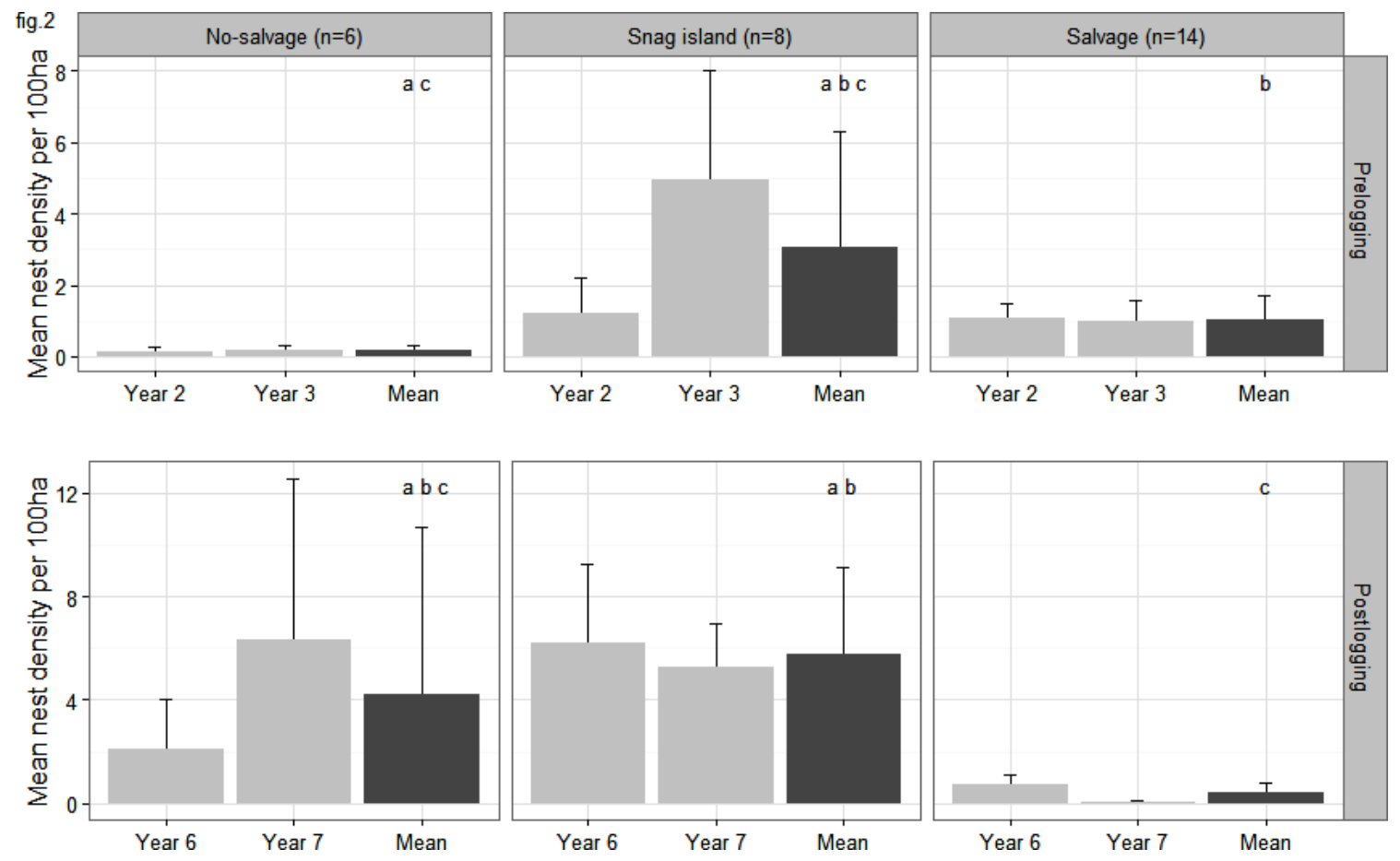

(11.5 ha). Following logging, average nest densities in the nosalvage units were higher than salvage units, although this trend was not significant (estimate $=0.23, \mathrm{SE}=0.13, \mathrm{z}=-2.58, p=0.10$ ).

\section{Nest-scale comparisons}

Average nest-site characteristics were similar between treatment types (Figs. 3 and 4) with significant differences in site characteristics attributed to sampling period only. In the postlogging sampling period, Black-backed Woodpeckers nested in significantly larger trees $(45.50 \pm 16.51 \mathrm{~cm})$ and more decayed trees (in areas that had a lower density of small diameter snags (108.29 \pm 108.57 per ha) than in the prelogging sampling period (snag diameter: $34.98 \pm 9.34 \mathrm{~cm} \mathrm{dbh}$; snag density: $193.14 \pm 210.16$ per ha), likely reflecting the disproportionate attrition and logging of smaller diameter trees. No significant interactions between sampling period and treatment type were found.

\section{DISCUSSION}

Previous studies have found very low densities of Black-backed Woodpeckers in salvage-logged areas, raising concerns regarding the impact of this postfire management action and the viability of Black-backed Woodpecker populations (Saab and Dudley 1998, Hutto 2006, Saab et al. 2007). Consistent with these studies, nesting densities of Black-backed Woodpeckers substantially declined in salvage units after implementation of logging while unlogged treatments increased over the same time period. This suggests that the decline observed in the salvage treatments was due to logging rather than natural population dynamics observed in unlogged habitat (Saab et al. 2007). However, by surveying the majority of the fire area, we found that the negative effect of logging appeared to be buffered by the snag islands and no-salvage units, which increased in mean density nonsignificantly. These increases were likely due to breeding pairs moving from logged to unlogged units after the logging was implemented (Fig. 1). Because we did not mark birds, we cannot be sure that new birds did not move into the fire as other birds left. However, a similar study on northern flying squirrels found that individuals moved to adjacent unlogged areas following logging in unburned forests, maintaining similar overall densities across the study area (Sollmann et al. 2016) and similar movements may occur in the Black-backed Woodpecker population.

In this study, Black-backed Woodpeckers built nests in patches of snags, which were retained within the salvage treatment both to serve as habitat reservoirs and for logistical reasons, suggesting a means by which salvage logging may be conducted to minimize negative impacts on Black-backed Woodpeckers. Despite their relatively small area $(\sim 4 \%, 54 \mathrm{ha})$ and the potential disturbance of logging, road construction, and edge effects, snag islands contained high concentrations of Black-backed Woodpecker nests in both the pre- and postlogging sampling periods. In addition, $58 \%$ of the Angora fire footprint along the perimeter was unlogged because of feasibility issues, and nesting densities of Black-backed Woodpeckers were relatively low in the prelogging period, but increased, albeit nonsignificantly, following logging. This raises the question as to whether the loss of habitat by salvage logging caused breeding birds to "make the best of a bad situation" by moving into suboptimal habitat (Battin 2004). However, our analysis indicates that nest sites were similar 
Fig. 3. Black-backed Woodpecker (Picoides arcticus) nest tree characteristics by treatment type before and after logging. ${ }^{\dagger}$ Diameter at breast height (DBH) of Black-backed Woodpecker nest trees averaged over all treatments was significantly higher in the post- than in the prelogging period $(\mathrm{F} 1,57=9.45, \mathrm{p}<0.01)$.
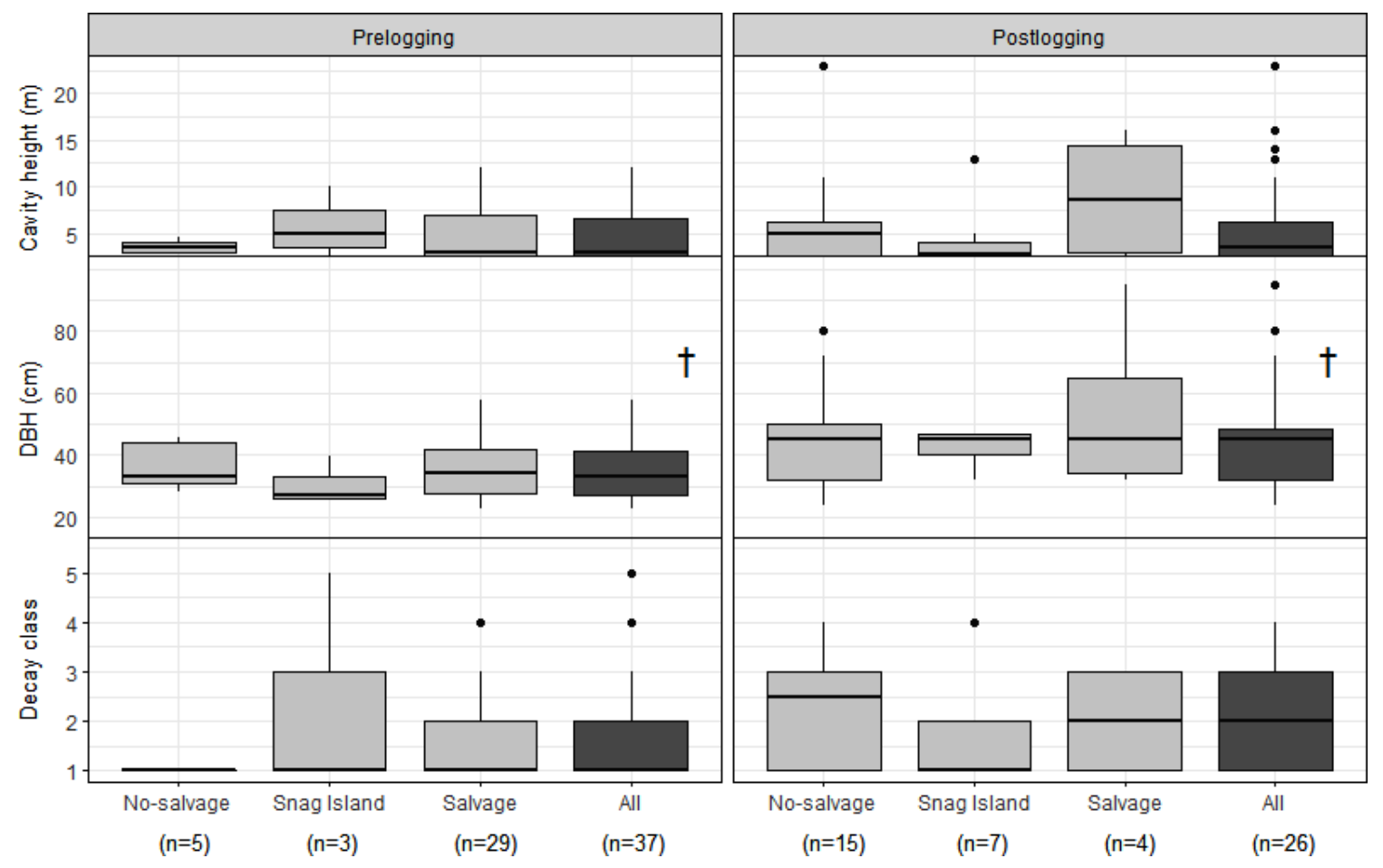

in all treatment types, with similar snags selected for nesting in stands of similar characteristics. The increase in mean nest density in no-salvage units may be due to improvements in habitat quality over time because they contained more areas that burned at moderate severity than the other treatment types and therefore may have more ongoing tree mortality over the seven years since fire (Angers et al. 2011). Newly recruited snags in these areas may have provided foraging and reproductive habitat for both woodboring beetles and Black-backed Woodpeckers (Nappi et al. 2010, Dudley et al. 2012). Snag densities were relatively high at nest sites both before ( 194 snags/ha for small diameter snags and $\sim 180$ snags/ha for medium diameter snags) and after ( 108 snags/ha for small diameter snags and 200 snags/ha for medium diameter snags) logging. Even nests in the salvage units in the postlogging period were placed in relatively dense stands of snags. These results are consistent with previous modeling efforts by White et al. (2015) that predict that the occurrence probability for Blackbacked Woodpeckers declines when snag densities decreased below 100-150 stems per ha in burned habitat. Thus, it appears that retention of snag islands and no-salvage areas has a positive effect on the persistence of Black-backed Woodpecker populations even in a matrix of high intensity salvage within the burned area.

The high cost of fighting fires and the elevated risk of future fires under climate change models (Westerling et al. 2006, Miller et al. 2009) argues for understanding economic and ecological risk and benefits associated with postfire management. From an economic standpoint, it is difficult to estimate the cost of snag islands and delays in operations. Restricting estimates to the cost of timber that was not harvested leaves many unknowns including market price, size and species of trees, and decay rates. However, some of these costs may be managed by locating snag islands in areas identified by surveys or models (Tingley et al. 2014) to be suitable Black-backed Woodpecker habitat that are not feasible to log because of access, soil conditions, or slope. Involving a multidisciplinary team that includes a wildlife biologist in the postfire planning process would help inform options for how to provide habitat for snag-associated species while also addressing economic, reforestation, and safety objectives. Although delays in salvage operations may severely reduce the value of postfire harvest, the removal of snags will still address concerns related to future fire risk and reforestation efforts.

Delaying logging operations may be an important factor for the retention of Black-backed Woodpeckers following salvage logging. Colonization of newly burned fires by Black-backed Woodpeckers seems to be largely the result of natal dispersal, given that there are higher proportions of younger birds in new fires than predicted based on global averages (Tremblay et al. 2015). Once territories are established, there is evidence that pairs remain in their territory for multiple years (Siegel et al. 2016), if nest success remains high (Rota 2013). Strong nest-site fidelity has been reported for other closely related species of woodpeckers (Kilham 1960, de Kiriline Lawrence 1967, Pechacek 2006) and it stands to reason that long-lived, resident species would maintain territories over multiple breeding seasons. Although most postfire logging operations take place in the first two years after fire, 
Fig. 4. Black-backed Woodpecker (Picoides arcticus) nest site characteristics by treatment type before and after logging. Burn severity was calculated as an area-weighted mean in a 100 m-radius buffer around each nest. Snag densities were calculated as stems per hectare by diameter class. ${ }^{\dagger}$ Density of small snags in Black-backed Woodpecker nest sites averaged over all treatments was significantly lower in the post- than in the prelogging period $(\mathrm{F} 1,56=5.25, \mathrm{p}=0.03)$.
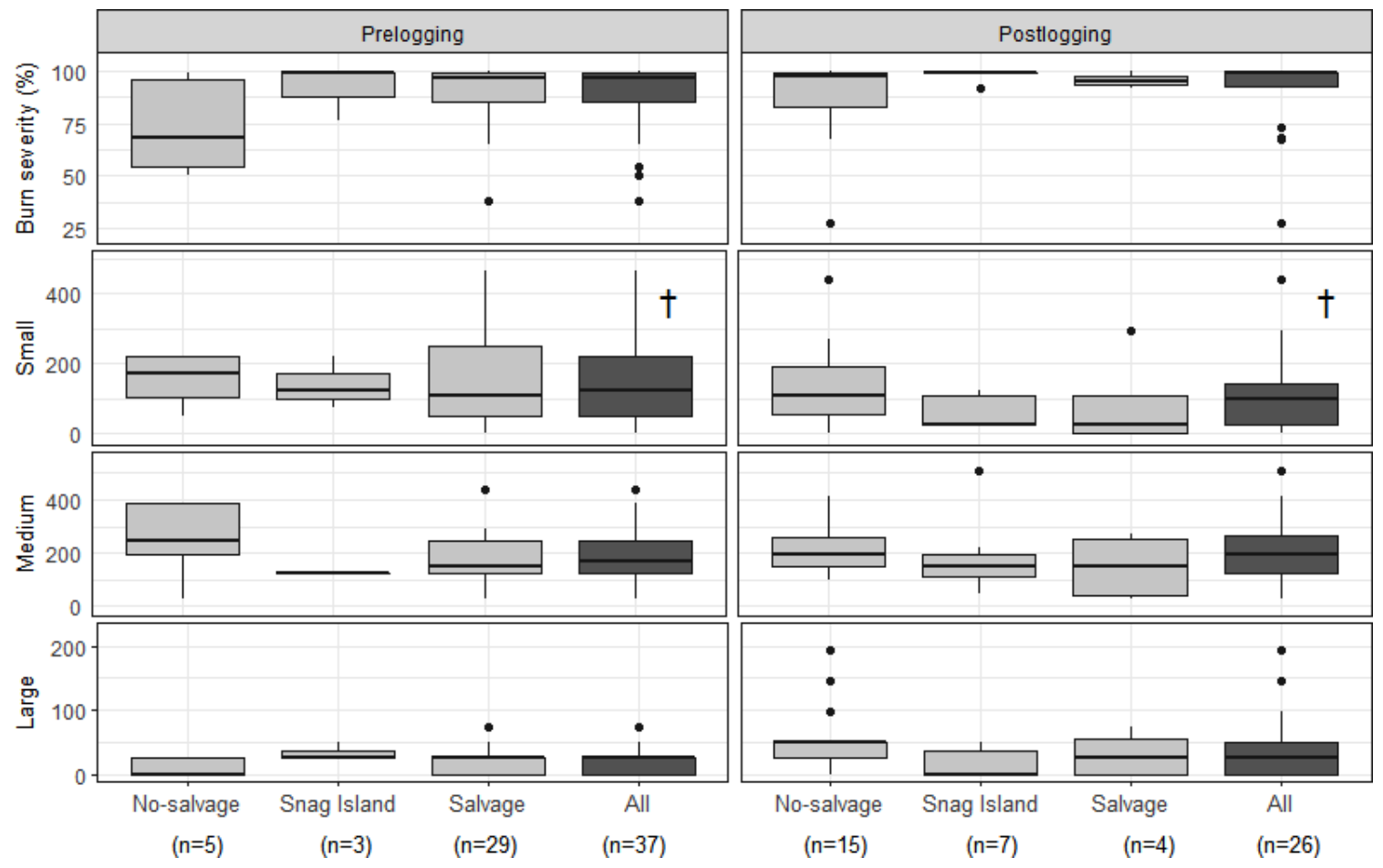

operations in the Angora fire were implemented in the fourth year postfire. This delay in salvage may have allowed the initial colonization by Black-backed Woodpeckers to occur undisturbed, with salvage operations taking place at the peak of woodpecker productivity (Saab et al. 2007). In the Angora fire, birds born after logging may simply disperse to higher quality habitat, whereas older birds that established territories in the four years prior to salvage must balance the energetic costs of relocating and establishing a territory with the residual reproductive value of their current territory. Delaying logging until after the peak population growth of Black-backed Woodpeckers may retain larger breeding populations, however, effects on population dynamics and persistence remain to be seen, and future research should focus on differences in reproductive success across types and timing of treatments.

An understanding of how postfire management reforestation goals can be reconciled with wildlife habitat is needed, but difficult to study. Our study was limited to the prescriptions designed and implemented by managers, which did not allow for a rigorous, well-replicated experiment with randomly placed salvage, nosalvage, and snag island treatments across the fire footprint. Instead, salvage treatments were placed with economic, logistic, and legal considerations, which may have resulted in the observed differences in nest densities between treatment types in the prelogging period. Similarly, because the goal of creating snag islands was to provide habitat for early-seral species, placement of these treatments was also nonrandom, confounding our results. However, given these limitations, we believe our results clearly show that in this study, Black-backed woodpeckers continued to nest in a fire area after extensive logging. Although this species is sensitive to the effects of salvage logging, we have shown individuals will nest in areas adjacent to or even within logged areas, if the appropriate habitat characteristics are available. It is important to note that we did not monitor nest success in this study. Generally, Black-backed Woodpeckers nesting in unlogged, burned forests are highly successful, with at least one offspring fledging in $70 \%$ to $100 \%$ of nests, depending on the region (Forristal 2009, Nappi and Drapeau 2009, Tremblay et al. 2016). The only record of a Black-backed Woodpecker nest that was monitored in a logged, burned forest was successful (Tremblay et al. 2016), however, logging may negatively impact reproductive success in several ways. Productivity may be lower if nesting and/ or foraging resources are patchier or scarcer (Nappi and Drapeau 2009), requiring individuals to spend more time foraging, interacting with competitors, and searching for adequate nest sites in logged habitat. In addition, habitat patches within the logged area may have increased edge effects, leading to higher nest predation rates (Fisher and Wiebe 2006). More research comparing nest success of Black-backed Woodpeckers in snag islands and other unlogged areas within the salvage matrix to unmanaged burned forest is needed to determine if these habitats are equivalent in supporting nesting populations. 
Fire is a natural disturbance that creates dynamic habitat conditions. High severity fire, in particular, results in a successional reset to ephemeral, early-seral habitat that supports a unique community of wildlife species specializing in postdisturbance landscapes (Hutto 2006). Postfire "restoration" is a burgeoning field of study as the acreage that experiences high severity fire increases in the West, when in fact, concerns over reforestation could overshadow the value of early-seral conditions and their unique contribution to biodiversity (Swanson et al. 2010, 2014, Donato et al. 2011). The Black-backed Woodpecker certainly qualifies as an early postfire associate and opportunist, where high densities of recently fire-killed snags serve to support an abundance of breeding pairs. The cues that trigger woodpecker pairs to commit to a particular fire area for the duration of their reproductive life is not well understood, but we speculate that a lack of disturbance in the first few years following a fire may be a factor in promoting sufficient site fidelity such that breeding pairs will tolerate some degree of habitat disturbance without abandoning their territory, as long as there are suitable habitat conditions elsewhere in the fire. Although there are economic trade-offs in postponing salvage logging, it appears there may be an ecological pay-off for the Black-backed Woodpecker in terms of boosting the reproductive output associated with a given fire, not to mention the myriad of other species that benefit from cavities created by woodpeckers, and the function that they play in jump-starting succession by establishing diverse postfire animal communities (Tarbill et al. 2015).

Responses to this article can be read online at: http://www.ace-eco.org/issues/responses.php/1206

\section{Acknowledgments:}

Financial support for this project was provided by the USDA Forest Service, Pacific Southwest Research Station, the Southern Nevada Public Lands Management Act, and the California Tahoe Conservancy. This research was conducted under U.S. Forest Service ethical considerations and involved only field observations; no animal was captured or handled. T.W. Richardson assisted with methodology and data collection. J. Baldwin and N. Johnston provided statistical advice. E. Newkirk assisted with database management. T. Biasiolli provided logistical support. Field assistance was provided by A. Arens, B. Campos, D. Gaube, K. Knox, S. Meloy, M. Rios, and K. Zummo. We thank the Lake Tahoe Basin Management Unit and D. Leao for logistical assistance and information on treatment prescriptions. This manuscript was improved by comments by $R$. Siegel. All authors shared the responsibilities of funding, design, implementation, analysis, and writing that resulted in this manuscript.

\section{LITERATURE CITED}

Angers, V. A., S. Gauthier, P. Drapeau, K. Jayen, and Y. Bergeron. 2011. Tree mortality and snag dynamics in North American boreal tree species after a wildfire: a long-term study. International Journal of Wildland Fire 20:751-763. http://dx.doi.org/10.1071/ WF10010
Battin, J. 2004. When good animals love bad habitats: ecological traps and the conservation of animal populations. Conservation Biology 18:1482-1491. http://dx.doi.org/10.1111/j.1523-1739.2004.00417. $\mathrm{x}$

Beaty, R. M., and A. H. Taylor. 2002. Spatial and temporal variation of fire regimes in a mixed conifer forest landscape, Southern Cascades, California, USA. Journal of Biogeography 28:955-966. http://dx.doi.org/10.1046/j.1365-2699.2001.00591.x

Beaty, R. M., and A. H. Taylor. 2008. Fire history and the structure and dynamics of a mixed conifer forest landscape in the northern Sierra Nevada, Lake Tahoe Basin, California, USA. Forest Ecology and Management 255:707-719. http://dx.doi. org/10.1016/j.foreco.2007.09.044

Bull, E. L., and E. C. Meslow. 1977. Habitat requirements of the pileated woodpecker in northeastern Oregon. Journal of Forestry 75:335-337.

Bull, E. L., C. G. Parks, and T. R. Torgersen. 1997. Trees and logs important to wildlife in the interior Columbia River basin. General Technical Report PNW-GTR-391. U.S. Forest Service, Pacific Northwest Research Station, Portland, Oregon, USA. http://dx. doi.org/10.2737/PNW-GTR-391

Buttrick, P. L. 1912. Notes on insect destruction of fire-killed timber in the Black Hills of South Dakota. Journal of Economic Entomology 5:456-464. http://dx.doi.org/10.1093/jee/5.6.456

Cline, S. P., A. B. Berg, and H. M. Wight. 1980. Snag characteristics and dynamics in Douglas-fir forests, western Oregon. Journal of Wildlife Management 44:773-786. http://dx. doi.org/10.2307/3808305

Collins, B. M., and G. B. Roller. 2013. Early forest dynamics in stand-replacing fire patches in the northern Sierra Nevada, California, USA. Landscape Ecology 28:1801-1813. http://dx.doi. org/10.1007/s10980-013-9923-8

Collins, B., and C. Skinner. 2014. Fire and fuels. General Technical Report. U.S. Forest Service, Pacific Southwest Research Station, Albany, California, USA.

Collins, B. M., and S. L. Stephens. 2010. Stand-replacing patches within a "mixed severity" fire regime: quantitative characterization using recent fires in a long-established natural fire area. Landscape Ecology 25:927-939. http://dx.doi. org/10.1007/s10980-010-9470-5

Coppoletta, M., K. E. Merriam, and B. M. Collins. 2015. Postfire vegetation and fuel development influences fire severity patterns in reburns. Ecological Applications 26:686-699. http://dx. doi.org/10.1890/15-0225

de Kiriline Lawrence, L. 1967. A comparative life-history study of four species of woodpeckers. Ornithological Monographs 5:1-156. http://dx.doi.org/10.2307/40166747

DeNitto, G., B. Cramer, K. Gibson, B. Lockman, T. McConnell, L. Stipe, N. Sturdevant, and J. Taylor. 2000. Survivability and deterioration of fire-injured trees in the northern Rocky Mountains: a review of the literature. The Bark Beetles, Fuels, and Fire Bibliography Report \#2000-13. 
Donato, D. C., J. L. Campbell, and J. F. Franklin. 2011. Multiple successional pathways and precocity in forest development: can some forests be born complex? Journal of Vegetation Science 23:576-584. http://dx.doi.org/10.1111/j.1654-1103.2011.01362.x

Dudley, J. G., and V. A. Saab. 2007. Home range size of Blackbacked Woodpeckers in burned forests of southwestern Idaho. Western North American Naturalist 67:593-600. http://dx.doi. org/10.3398/1527-0904(2007)67[593:HRSOBW]2.0.CO;2

Dudley, J. G., V. A. Saab, and J. P. Hollenbeck. 2012. Foraginghabitat selection of Black-backed Woodpeckers in forest burns of southwestern Idaho. Condor 114:348-357. http://dx.doi. org/10.1525/cond.2012.110020

Eklund, A., M. G. Wing, and J. Sessions. 2009. Evaluating economic and wildlife habitat considerations for snag retention policies in burned landscapes. Western Journal of Applied Forestry 24:67-75.

Fisher, R. J., and K. L. Wiebe. 2006. Nest site attributes and temporal patterns of Northern Flicker nest loss: effects of predation and competition. Oecologia 147:744-753. http://dx.doi. org/10.1007/s00442-005-0310-2

Fogg, A. M., L. J. Roberts, and R. D. Burnett. 2014. Occurrence patterns of Black-backed Woodpeckers in green forest of the Sierra Nevada Mountains, California, USA. Avian Conservation and Ecology 9(2):3. http://dx.doi.org/10.5751/ACE-00671-090203

Forristal, C. D. 2009. Influence of postfire salvage logging on Black-backed Woodpecker nest-site selection and nest survival. Dissertation. Montana State University-Bozeman, College of Letters \& Science, Bozeman, Montana, USA.

Furniss, R. L., and V. M. Carolin. 1977. Western forest insects. U.S. Department of Agriculture, Forest Service, Washington, D. C., USA. http://dx.doi.org/10.5962/bhl.title.131875

Goforth, B. R., and R. A. Minnich. 2008. Densification, standreplacement wildfire, and extirpation of mixed conifer forest in Cuyamaca Rancho State Park, southern California. Forest Ecology and Management 256:36-45. http://dx.doi.org/10.1016/j. foreco.2008.03.032

Hutto, R. L. 2006. Toward meaningful snag-management guidelines for postfire salvage logging in North American conifer forests. Conservation Biology 20:984-993. http://dx.doi. org/10.1111/j.1523-1739.2006.00494.x

Kilham, L. 1960. Courtship and territorial behavior of Hairy Woodpeckers. Auk 77:259-270. http://dx.doi.org/10.2307/4082482

Lenth, R. V. 2016. Least-squares means: the R package lsmeans. Journal of Statistical Software 69:1-33. http://dx.doi. org/10.18637/jss.v069.i01

Lindström, S., P. Rucks, and P. Wigand. 2000. A contextual overview of human land use and environmental conditions. Lake Tahoe Watershed Assessment 1:23-127.

Lorenz, T. J., K. T. Vierling, T. R. Johnson, and P. C. Fischer. 2015. The role of wood hardness in limiting nest site selection in avian cavity excavators. Ecological Applications 25:1016-1033. http://dx.doi.org/10.1890/14-1042.1

Lydersen, J. M., B. M. Collins, M. L. Brooks, J. R. Matchett, K. L. Shive, N. A. Povak, V. R. Kane, and D. F. Smith. 2017. Evidence of fuels management and fire weather influencing fire severity in an extreme fire event. Ecological Applications 27:2013-2030. http://dx.doi.org/10.1002/eap.1586

Martin, T. E., and G. R. Geupel. 1993. Nest-monitoring plots: methods for locating nests and monitoring success (Métodos para localizar nidos y monitorear el éxito de estos). Journal of field Ornithology 64:507-519.

McClelland, B. R., and S. S. Frissell. 1975. Identifying forest snags useful for hole-nesting birds. Journal of Forestry 73:414-417.

McKelvey, K. S., C. N. Skinner, C. Chang, D. C. Erman, S. J. Husari, D. J. Parsons, J. W. van Wagtendonk, and C. P. Weatherspoon. 1996. An overview of fire in the Sierra Nevada. Pages 1033-1040 in Sierra Nevada Ecosystem Project, Final Report to Congress, Vol. II, Assessments and Scientific Basis for Management Options. Centers for Water and Wildland Resources. Report No. 37. University of California, Davis, California, USA.

Miller, J. D., H. D. Safford, M. Crimmins, and A. E. Thode. 2009. Quantitative evidence for increasing forest fire severity in the Sierra Nevada and southern Cascade Mountains, California and Nevada, USA. Ecosystems 12:16-32. http://dx.doi.org/10.1007/ s10021-008-9201-9

Murphy, E. C., and W. A. Lehnhausen. 1998. Density and foraging ecology of woodpeckers following a stand-replacement fire. Journal of Wildlife Management 62:1359-1372. http://dx.doi. org/10.2307/3802002

Nappi, A., and P. Drapeau. 2009. Reproductive success of the Black-backed Woodpecker (Picoides arcticus) in burned boreal forests: Are burns source habitats? Biological Conservation 142:1381-1391. http://dx.doi.org/10.1016/j.biocon.2009.01.022

Nappi, A., and P. Drapeau. 2011. Pre-fire forest conditions and fire severity as determinants of the quality of burned forests for deadwood-dependent species: the case of the Black-backed Woodpecker. Canadian Journal of Forest Research 41:994-1003. http://dx.doi.org/10.1139/x11-028

Nappi, A., P. Drapeau, and A. Leduc. 2015. How important is dead wood for woodpeckers foraging in eastern North American boreal forests? Forest Ecology and Management 346:10-21. http:// dx.doi.org/10.1016/j.foreco.2015.02.028

Nappi, A., P. Drapeau, M. Saint-Germain, and V. A. Angers. 2010. Effect of fire severity on long-term occupancy of burned boreal conifer forests by saproxylic insects and wood-foraging birds. International Journal of Wildland Fire 19:500-511. http:// dx.doi.org/10.1071/WF08109

Nappi, A., P. Drapeau, and J.-P. L. Savard. 2004. Salvage logging after wildfire in the boreal forest: Is it becoming a hot issue for wildlife? Forestry Chronicle 80:67-74. http://dx.doi.org/10.5558/ tfc80067-1

North, M., B. M. Collins, and S. Stephens. 2012. Using fire to increase the scale, benefits, and future maintenance of fuels treatments. Journal of Forestry 110:392-401. http://dx.doi. org/10.5849/jof.12-021

Pechacek, P. 2006. Breeding performance, natal dispersal, and nest site fidelity of the three-toed woodpecker in the German Alps. Annales Zoologici Fennici 43:165-176. 
Purdon, M., J. Noël, A. Nappi, P. Drapeau, B. Harvey, S. Brais, Y. Bergeron, S. Gauthier, and D. Greene. 2002. The impact of salvage-logging after wildfire in the boreal forest: lessons from the Abitibi. NSERC-UQAT-UQAM Industrial Chair in Sustainable Forest Management, Abitibi, Québec, Canada.

R Development Core Team. 2018. R: A language and environment for statistical computing. R Foundation for Statistical Computing, Vienna, Austria. [online] URL: https://www.R-project.org/

Raphael, M. G., and M. White. 1978. Snags, wildlife, and forest management in the Sierra Nevada. Cal-Nevada Wildlife:23-41.

Richmond, H. A., and R. R. Lejeune. 1945. The deterioration of fire-killed white spruce by wood-boring insects in northern Saskatchewan. Forestry Chronicle 21:168-192. http://dx.doi. org/10.5558/tfc21168-3

Rota, C. T. 2013. Not all forests are disturbed equally: population dynamics and resource selection of Black-backed Woodpeckers in the Black Hills, South Dakota. Dissertation. University of Missouri-Columbia, Missouri, USA.

Russell, R. E., V. A. Saab, J. G. Dudley, and J. J. Rotella. 2006. Snag longevity in relation to wildfire and postfire salvage logging. Forest Ecology and Management 232:179-187. http://dx.doi. org/10.1016/j.foreco.2006.05.068

Saab, V. A., and J. G. Dudley. 1998. Responses of cavity-nesting birds to stand-replacement fire and salvage logging in ponderosa pine/Douglas-fir forests of southwestern Idaho. Res. Pap. RMRSRP-11. U.S. Forest Service, Rocky Mountain Research Station, Ogden, Utah, USA. http://dx.doi.org/10.2737/RMRS-RP-11

Saab, V. A., R. E. Russell, and J. G. Dudley. 2007. Nest densities of cavity-nesting birds in relation to postfire salvage logging and time since wildfire. Condor 109:97-108. http://dx.doi. org/10.1650/0010-5422(2007)109[97:NDOCBI]2.0.CO;2

Saab, V. A., R. E. Russell, and J. G. Dudley. 2009. Nest-site selection by cavity-nesting birds in relation to postfire salvage logging. Forest Ecology and Management 257:151-159. http://dx. doi.org/10.1016/j.foreco.2008.08.028

Safford, H. D., D. A. Schmidt, and C. H. Carlson. 2009. Effects of fuel treatments on fire severity in an area of wildland-urban interface, Angora Fire, Lake Tahoe Basin, California. Forest Ecology and Management 258:773-787. http://dx.doi.org/10.1016/ j.foreco.2009.05.024

Saracco, J. F., R. B. Siegel, and R. L. Wilkerson. 2011. Occupancy modeling of Black-backed Woodpeckers on burned Sierra Nevada forests. Ecosphere 2:1-17. http://dx.doi.org/10.1890/ ES10-00132.1

Seavy, N. E., R. D. Burnett, and P. J. Taille. 2012. Black-backed Woodpecker nest-tree preference in burned forests of the Sierra Nevada, California. Wildlife Society Bulletin 36:722-728. http:// dx.doi.org/10.1002/wsb.210

Sessions, J., P. Bettinger, R. Buckman, M. Newton, and J. Hamann. 2004. Hastening the return of complex forests following fire: the consequences of delay. Journal of Forestry 102:38-45.

Siegel, R. B., M. W. Tingley, R. L. Wilkerson, C. A. Howell, M. Johnson, and P. Pyle. 2016. Age structure of Black-backed
Woodpecker populations in burned forests. Auk 133:69-78. http:// dx.doi.org/10.1642/AUK-15-137.1

Sollmann, R., A. M. White, G. L. Tarbill, P. N. Manley, and E. E. Knapp. 2016. Landscape heterogeneity compensates for fuel reduction treatment effects on Northern flying squirrel populations. Forest Ecology and Management 373:100-107. http:// dx.doi.org/10.1016/j.foreco.2016.04.041

Swanson, M. E., J. F. Franklin, R. L. Beschta, C. M. Crisafulli, D. A. DellaSala, R. L. Hutto, D. B. Lindenmayer, and F. J. Swanson. 2010. The forgotten stage of forest succession: earlysuccessional ecosystems on forest sites. Frontiers in Ecology and the Environment 9:117-125. http://dx.doi.org/10.1890/090157

Swanson, M. E., N. M. Studevant, J. L. Campbell, and D. C. Donato. 2014. Biological associates of early-seral pre-forest in the Pacific Northwest. Forest Ecology and Management 324:160-171. http://dx.doi.org/10.1016/j.foreco.2014.03.046

Tarbill, G. L. 2010. Nest site selection and influence of woodpeckers on recovery in a burned forest of the Sierra Nevada. Thesis. California State University, Sacramento, California, USA.

Tarbill, G. L., P. N. Manley, and A. M. White. 2015. Drill, baby, drill: the influence of woodpeckers on post-fire vertebrate communities through cavity excavation. Journal of Zoology 296:95-103. http://dx.doi.org/10.1111/jzo.12220

Taylor, A. H., and R. M. Beaty. 2005. Climatic influences on fire regimes in the northern Sierra Nevada mountains, Lake Tahoe Basin, Nevada, USA. Journal of Biogeography 32:425-438. http:// dx.doi.org/10.1111/j.1365-2699.2004.01208.x

Taylor, A. H., A. M. Vandervlugt, R. S. Maxwell, R. M. Beaty, C. Airey, and C. N. Skinner. 2013. Changes in forest structure, fuels and potential fire behaviour since 1873 in the Lake Tahoe Basin, USA. Applied Vegetation Science 17:17-31. http://dx.doi. org/10.1111/avsc.12049

Thomas, J. W., R. G. Anderson, C. Maser, and E. L. Bull. 1979. Snags. Wildlife habitats in managed forests-the Blue Mountains of Oregon and Washington. Agricultural Handbook 553:60-77.

Thompson, J. R., and T. A. Spies. 2010. Factors associated with crown damage following recurring mixed-severity wildfires and post-fire management in southwestern Oregon. Landscape Ecology 25:775-789. http://dx.doi.org/10.1007/s10980-010-9456-3

Tingley, M. W., R. L. Wilkerson, M. L. Bond, C. A. Howell, and R. B. Siegel. 2014. Variation in home-range size of Black-backed Woodpeckers. Condor 116:325-340. http://dx.doi.org/10.1650/ CONDOR-13-140.1

Tremblay, J. A., R. D. Dixon, V. A. Saab, P. Pyle, and M. A. Patten. 2016. Black-backed Woodpecker (Picoides arcticus). Version 3.0. In P. G. Rodewald, editor. The birds of North America, Cornell Lab of Ornithology, Ithaca, New York, USA. https://doi. org/10.2173/bna.bkbwoo.03. http://dx.doi.org/10.2173/bna.bkbwoo.03

Tremblay, J. A., J. Ibarzabal, C. Dussault, and J.-P. L. Savard. 2009. Habitat requirements of breeding Black-backed Woodpeckers (Picoides arcticus) in managed, unburned boreal forest. Avian Conservation and Ecology 4(1):2. http://dx.doi. org/10.5751/ACE-00297-040102 
Tremblay, J. A., J. Ibarzabal, and J.-P. L. Savard. 2015. Contribution of unburned boreal forests to the population of Black-backed Woodpecker in eastern Canada. Écoscience 22:145-155. http://dx.doi.org/10.1080/11956860.2016.1169386

U.S. Forest Service. 2010a. Angora fire restoration project environmental assessment, final. Lake Tahoe Basin Management Unit, Region 5, South Lake Tahoe, California, USA.

U.S. Forest Service. 2010b. Angora fire restoration project decision notice and finding of no significant impact. Lake Tahoe Basin Management Unit, Region 5, South Lake Tahoe, California, USA.

Villard, P., and C. W. Beninger. 1993. Foraging behavior of male Black-backed and Hairy Woodpeckers in a forest burn (Conducta de Forrajeo de Individuos Machos de los Carpinteros Picoides villosus y P. arcticus en un Área Forestal Quemada). Journal of Field Ornithology 64:71-76.

Westerling, A. L., H. G. Hidalgo, D. R. Cayan, and T. W. Swetnam. 2006. Warming and earlier spring increase western U. S. forest wildfire activity. Science 313:940-943. http://dx.doi. org/10.1126/science. 1128834

White, A. M., P. N. Manley, G. L. Tarbill, T. W. Richardson, R. E. Russell, H. D. Safford, and S. Z. Dobrowski. 2015. Avian community responses to post-fire forest structure: implications for fire management in mixed conifer forests. Animal Conservation 19:256-264. http://dx.doi.org/10.1111/acv.12237 
Appendix 1: Burn severity, area searched, and number of nests in each treatment unit by year.

\begin{tabular}{|c|c|c|c|c|c|c|c|c|c|c|}
\hline \multirow{3}{*}{ Treatment unit } & & & \multicolumn{2}{|c|}{ Year 2} & \multicolumn{2}{|c|}{ Year 3} & \multicolumn{2}{|c|}{ Year 6} & \multicolumn{2}{|c|}{ Year 7} \\
\hline & \multicolumn{2}{|c|}{$\begin{array}{c}\text { Burn severity area- } \\
\text { weighted mean }\end{array}$} & $\begin{array}{l}\text { Search } \\
\text { area }\end{array}$ & $\begin{array}{l}\text { Number } \\
\text { of nests }\end{array}$ & $\begin{array}{l}\text { Search } \\
\text { area }\end{array}$ & $\begin{array}{l}\text { Number } \\
\text { of nests }\end{array}$ & $\begin{array}{l}\text { Search } \\
\text { area }\end{array}$ & $\begin{array}{l}\text { Number } \\
\text { of nests }\end{array}$ & $\begin{array}{l}\text { Search } \\
\text { area }\end{array}$ & $\begin{array}{l}\text { Number } \\
\text { of nests }\end{array}$ \\
\hline & category & $(\%)$ & (ha) & & (ha) & & (ha) & & (ha) & \\
\hline No-salvage 1 & moderate & 29 & 26.53 & 0 & 27.09 & 0 & 28.85 & 0 & 27.09 & 1 \\
\hline No-salvage 2 & moderate & 51 & 56.62 & 0 & 81.09 & 1 & 81.09 & 0 & 81.09 & 1 \\
\hline No-salvage 3 & moderate & 26 & 0.18 & 0 & 0.94 & 0 & 0.94 & 0 & 0.94 & 0 \\
\hline No-salvage 4 & low & 8 & 4.67 & 0 & 4.91 & 0 & 4.91 & 0 & 4.91 & 0 \\
\hline No-salvage 5 & moderate & 71 & 19.13 & 0 & 19.13 & 0 & 19.13 & 0 & 19.13 & 0 \\
\hline No-salvage 6 & moderate & 50 & 88.64 & 1 & 88.64 & 0 & 88.64 & 0 & 88.64 & 0 \\
\hline No-salvage 7 & moderate & 60 & 111.95 & 1 & 163.04 & 2 & 161.01 & 7 & 161.01 & 4 \\
\hline No-salvage 8 & high & 99 & 2.59 & 0 & 2.59 & 0 & 2.59 & 0 & 2.59 & 0 \\
\hline No-salvage 9 & high & 100 & 1.11 & 0 & 1.11 & 0 & 1.11 & 0 & 1.11 & 0 \\
\hline No-salvage 10 & high & 100 & 1.27 & 0 & 1.27 & 0 & 1.27 & 0 & 1.27 & 0 \\
\hline No-salvage 11 & high & 100 & 1.23 & 0 & 1.23 & 0 & 1.23 & 0 & 1.23 & 1 \\
\hline No-salvage 12 & high & 77 & 6 & 0 & 6 & 0 & 6 & 0 & 6 & 0 \\
\hline No-salvage 13 & high & 98 & 4.43 & 0 & 4.43 & 0 & 4.43 & 0 & 4.43 & 0 \\
\hline No-salvage 14 & high & 100 & 4.01 & 0 & 4.01 & 0 & 4.01 & 1 & 4.01 & 0 \\
\hline Snag island 1 & high & 100 & 3.36 & 0 & 3.36 & 1 & 3.36 & 1 & 3.36 & 0 \\
\hline Snag island 2 & high & 100 & 11.51 & 0 & 11.51 & 0 & 11.51 & 0 & 11.51 & 1 \\
\hline Snag island 3 & high & 84 & 10.26 & 1 & 10.26 & 1 & 10.26 & 1 & 10.26 & 1 \\
\hline Snag island 4 & high & 100 & 3.25 & 0 & 3.25 & 0 & 3.25 & 0 & 3.25 & 0 \\
\hline Snag island 5 & high & 100 & 9.97 & 0 & 9.97 & 0 & 9.97 & 1 & 9.97 & 1 \\
\hline Snag island 6 & high & 99 & 3.86 & 0 & 3.86 & 0 & 3.86 & 0 & 3.86 & 0 \\
\hline Snag island 7 & high & 99 & 3.72 & 0 & 7.25 & 0 & 7.25 & 0 & 7.25 & 1 \\
\hline Snag island 8 & high & 99 & 4.54 & 0 & 4.54 & 0 & 4.54 & 0 & 4.54 & 0 \\
\hline Salvage 1 & moderate & 26 & 3.57 & 0 & 3.65 & 0 & 3.65 & 0 & 3.65 & 0 \\
\hline Salvage 2 & high & 93 & 95.99 & 2 & 96.07 & 1 & 96.1 & 1 & 96.07 & 0 \\
\hline Salvage 3 & moderate & 62 & 1.27 & 0 & 31.84 & 0 & 31.84 & 1 & 31.84 & 0 \\
\hline Salvage 4 & high & 89 & 1.38 & 0 & 7.7 & 0 & 7.7 & 0 & 7.7 & 0 \\
\hline Salvage 5 & high & 83 & 310.53 & 10 & 319.95 & 16 & 319.95 & 1 & 319.95 & 1 \\
\hline Salvage 6 & high & 86 & 0 & 0 & 0.77 & 0 & 0.77 & 0 & 0.77 & 0 \\
\hline
\end{tabular}

